\section{The Strategies of Learning Writing Used by EFL Learners at a Higher Education Institution}

\author{
1 Rika Junianti \\ 2 Bambang Widi Pratolo \\ 3 Arifiana Tri Wulandari
}

123 Universitas Ahmad Dahlan, Indonesia

\begin{abstract}
Writing is the process of structuring ideas and sharpening intelligence. The students should understand and think about many things to produce good writing. This research addresses two research objectives: (1) what strategies the students use in learning writing skills, and (2) what problems the students have in learning the writing skill. The subjects of this study are $35 \mathrm{EFL}$ students of English Departments in an Indonesian higher education institution. They were invited to complete a questionnaire of strategies in learning writing skills, and six of them were asked to have an interview about the problems during the learning process. The strategies are based on the stages of the writing process (planning, execution, and revision), which in this research were presented in three model factors (cognitive, metacognitive, and social strategies). The result showed that the average use for each strategy is as follows, $79 \%$ for metacognitive strategy, $74 \%$ for cognitive strategy, and $81 \%$ for social strategy. Regarding the second goal of this study, the problems that the students faced in learning writing include grammar and vocabulary issues.
\end{abstract}

\section{Keywords}

language learning strategies

writing skill

writing strategies

EFL

\section{Ethical Lingua}

Vol. 7, No. 1, 2020

ISSN 2355-3448 (Print)

ISSN 2540-9190 (Online)

Corresponding Email

Bambang Widi Pratolo

bambang.pratolo@pbi.uad.ac. id

Article's History

Submitted 25 Nov 2019

Revised 24 December 2019

Revised 20 February 2020

Accepted 3 April 2020

\section{DOI}

10.30605/25409190.131

Copyright $\odot 2020$

The Author(s)

This article is licensed under CC BY-NC-SA 4.0 License

\section{(c) EY-NC-SA}




\section{The Strategies of Learning Writing Used by EFL Learners at a Higher Education Institution}

Writing is one of the important skills for learners, especially for those who are studying in English Department. Although writing courses have been designed to help students acquire good writing skills, most students still struggle to produce good writing. It is not only that they have insufficient knowledge on how to structure ideas, but also how to write in an acceptable structured sentence and choose the correct dictions. That is why they are often found to copy and paste ideas from different sources and put them together, which sometimes are so meaningless. They do not seem to know how to paraphrase ideas and how to cite others' opinions in their writing. Whereas this kind of skill is so significant in academic writing, especially as they have to write a thorough writing report of their research, which is called "skripsi" (bachelor's thesis) as one of the requirements of their bachelor completion.

Writing is the process of structuring ideas which can sharpen the intelligence. The learners should understand and think of many things to produce good writing. According to Harmer (2004), there are many advantages of learning writing, including: first, writing does not have a time limit, which is different from conversation. It means that writing is different from speaking because in writing, students can prepare and edit the writing pattern in a longer time. Second, the students can write while they think about the idea so that they get good motivation. This is the process of composing writing that is influenced by the learning in the class. The brain will inform the language to be written.

The language strategies consist of three types, meta-cognitive, cognitive, and social strategies. The first strategy, meta-cognitive, which is also called mental process helps the learners monitor their own learning. The meta-cognitive process also helps the learners in learning, which includes planning, deciding to choose how they learn, and the last is evaluating their learning (O'Malley, Chamot, Walker \& Sabol, 1987). Moreover, Ellis, Denton, \& Bond (2014) say that the stages of the learning process include planning, monitoring, and evaluating. The second is cognitive strategy which involves mental processes. This process deals with choosing relevant information/source (Kalati, 2016; Montaño-González, 2017). The last social strategy deals with how students interact with other speakers. It aims to develop learner cultural understanding (Kalati, 2016; Shi, 2017).

This research applied Vygotsky's sociocultural theory as the theoretical framework (Habók \& Magyar, 2018), including 1) Strategic Self-Regulation (S2R); 2) model of L2 learning (Oxford R. L., 2011 as cited in Jin, Jiang, Zhang, Yuan, Liang \& Xie, 2014) which is a continuation of Vygotsky's model of 'dialogic, self-regulated learning (ibid: 28); and 3) social-cognitive model of self-regulated learning Zimmerman cited in (Stephanou \& Mpiontini, 2017). These concepts of theories are the learning characteristic of language learners. They are responsible and implicate in their own learning. The model consists of six strategy groups: metacognitive, meta-affective, meta-sociocultural-interactive, cognitive, affective, and socioculturalinteractive. The theory is an elaboration of the earlier taxonomy of (Oxford, 2017). Zimmerman Model (2016) presents the learners on their perceived effectiveness. The learners have the enthusiasm to use learning strategy. It is measured by the effectiveness of past learners' goals. 
Taxonomy of language learning strategies by Oxford (2017) stated that there are two strategies of language learning, including direct and indirect strategies. Indirect strategies consist of memory, cognitive, and compensation, while direct strategies consist of metacognitive, effective, and social. Direct strategies are real language performance, while indirect strategies are the plan and the organization of learning. In the 1970s, the product approach became the target of criticism as the researches and educators believed in cognitivist philosophy and switched their attention from the product to the writers. This approach is famous as the process. The approach is developed from L1 writing that describes the meaningful messages of the writer based on mental processes. According to Raimes cited in Aygün \& Aydin (2016), the steps follow accuracy, pattern, and process, meaning creation, invention, and multiple drafts'. The first concern of the text is the cognitive activities of the writers. The activities are producing ideas, execution, and revision, and the last is getting the feedback.

The theoretical framework applied in this research consists of sociocultural theory, Zimmerman's social-cognitive model, and self-regulated learning. Davidson (2007) argues that the role of teachers is very important, and they are taking to guide instruction and writing process such as peer interaction as process model form. The process model is called cognitive activity. The approach is contrasted with the writing. It becomes the basis of writing cognitive process theory. The theory model from (Hayes \& Flower, 2015) stated that the cognitive approach is caused by the social dimension. Teaching and learning are social dimensions of writing strategy. The writing involved a set of intricate sources. It includes the content of knowledge. It is namely linguistic knowledge, and it contains grammar, vocabulary, text structure, and the understanding of the strategy which provides appropriate information. The learners realize how the process of their learning, and what makes them effective in learning (Oxford, 2017).

Mistar, Zulhairi, \& Parlindungan (2015) involved matrix elements by using varimax and normalization methods. It results in some factors as posterior strategy categories. They are self-monitoring, language-focused, planning, metacognitive affective, cognitive compensation, self-evaluation, social process-focused, authentic practice, meaning-focused, vocabulary development, metacognitive commencement, and mental processing strategies. The categories took Indonesian students as learners of English writing. Finally, successful learners were found to use all of the twelve strategies more frequently than those of the less successful learners.

On the other hand, Kieft, Rijllaarsdam, \& Bergh (2008), as cited in Tillema, Bergh, Rijlaarsdam, \& Sanders (2011) conducted the study on the effectiveness of writing by doing assignments as different writing strategies. The method included planning and revising. The participants were 113 tenth grade high school students in the Netherlands. The study dealt with the plan of writing and found these strategies to be effective in improving literary interpretation skills. Another study by Torrance, Thomas, \& Robinson (1994) investigated writing strategies, where the subjects of the study are graduate research students, especially the social sciences students in the UK. They were divided into three categories: planners, revisers, and mixed strategy writers. The planners showed higher productivity than the two strategy writers. The study concludes that planning can be effective for some students, but planning itself will not guarantee the success of writing. Meanwhile, Ruhama \& Purwaningsih (2018) improved the students' writing skills through the application of Synectic model of teaching using audiovisual media. They involved junior high school students as the subjects of the study. 
Implementing a mixed method approach, Salikin, Bin-Tahir, \& Emelia (2017) conducted a research to know the learning strategies and its role used by high achiever students and the advantages of the strategies. They found that metacognitive strategies are high strategies followed by compensation strategies, cognitive strategies, social strategies, affective strategies, and memory strategies. They concluded that in higher education, there are six strategies that are commonly employed by students to make English language learning successful.

The study by Bai, Hu, \& Gu (2014) investigated English writing strategies used by the primary school students in Singapore, and what the students reported after using the writing strategies in different English proficiency. Writing strategies focus on metacognition, cognition, and social or affective strategies. Metacognition consists of self-initiation, planning, and monitoring or evaluating. Planning strategy was more often used than other strategies. In addition, group strategies were related to English language proficiency, and they had developed writing strategies in different English proficiency. Another study by Maarof \& Murat (2013), stated that the strategies focused on pre-writing, writing, and revising. Writing was more frequently used than pre-writing and revising. In China, there were problems in learning writing on the campus, especially in English courses. This analysis is about the difficulties, approaches, and strategies in English writing, appearance in attitude, sources in writing, and self-evaluation.

Furthermore, Yusuf, Jusoh, \& Yusuf (2019) conducted the study to investigate the effects of Cooperative Learning $(\mathrm{CL})$ to improve the writing skill of ninth-grade students in Kuala Lumpur. They used quantitative method which is categorized as quasi-experimental research. The result of the study revealed that CL strategy has a good impact on improving students' abilities, especially in writing skills. The researchers used five components, such as content, organization, vocabulary, grammar, and mechanics. The importance of writing skills is to write not only articles, but also papers, journals, research reports, and research proposal. The result of students' writing is a manifestation of their creativity and knowledge. They may present them in the form of papers, thesis, and proposed research. Tawalbeh \& Al-zuoud (2013) found that students can get better knowledge by conducting research papers, and they can achieve a better ability in writing.

On the same topic of students' writing strategies, Mistar, Zulhairi, \& Parlindungan (2014) involved a massive number of senior high school students to fill up a questionnaire to identify their writing strategies. Descriptive and ex-post design was used in their study. Yusuf, Jusoh, \& Yusuf (2018) employed quasi-experimental design by asking the students to write narrative texts to find the effectiveness of writing strategies while Tawalbeh \& Al-zuoud (2013) chose 40 nursing students with descriptive correlational design to identify their writing strategies. Different from those studies, this present study used mixed-method design by combining questionnaire and semi-structured interview to achieve the research questions. The subjects of this study were also specific in that they were the students of English department of which writing skill is crucial to all subjects they take. Specifically, the goal of this study is to investigate the strategies of writing strategies used in English classes. To achieve this goal, the following research questions are proposed; (1) what strategies do the students use in learning writing skills? (2) what problems do they encounter in learning writing skills? 


\section{Method}

\section{The study designs}

This study used mixed-method design to investigate what strategies of learning writing used by EFL learners in higher education, and what problems the learners have in learning writing.

\section{The sample population or subject of the research}

The subjects of this research are EFL learners who are registered as active students in an Indonesian higher education aged mostly between 18 until 22 years old. They have all courses by using English language. Writing is one of the skills that must be mastered by the students. Writing is an important skill the students always need to do the assignments. Therefore, the students are expected to have good writing skills with grammatical and lexical knowledge and broad ideas to make their writing academically sound.

\section{Data collection techniques and instrument development}

This study used questionnaire and semi-structured interviews as data collection tools. This quantitative method was held as follows: first, the participants filled in the questionnaire about the strategy of learning writing. The questionnaire consisted of thirty questions. The questionnaires were prepared in Indonesian language to help the students understand fully and avoid any misunderstanding. Out of fifty students, thirty of them returned the questionnaires. The second was an interview. This interview was about problems that the students have in learning writing. The interview involved six students who really had problems with writing.

\section{Data analysis techniques}

The researcher also used the taxonomy of writing strategies according to the stages of the writing process (planning, execution, and revision), which followed the above-mentioned three-factor models (cognitive, metacognitive, and social strategies) for the purpose of data analysis.

\section{Results}

\section{Strategies in learning writing}

There were 35 correspondents, and they had filled a questionnaire about strategies in learning writing. The questionnaire consisted of 30 five-point Likert scale statements that were related to the stages of the writing process, and this Likert scale questions were divided into three sections, namely: planning, execution, and revision. It was then classified into C-Cognitive, M-Metacognitive, and S-Social in the writing strategy questionnaire in order to find out what strategies that the students use in learning writing. The researchers used Microsoft Excel 2016 to calculate the questionnaire result.

From the three strategies, metacognitive strategy was accounted for $138.1(79 \%)$. This strategy is related to outlining and planning before writing. It mainly deals with reading that related to the topic; planning the text organization, practicing grammatical structure, preparing the vocabulary, idea, and example of writing; and giving a reward to self, such as short break, 
which is done to refresh the brain. In addition, this strategy is also to evaluate the writing result. The evaluation of writing includes content, grammar, and vocabulary review.

Table 1. Questionnaire result

\begin{tabular}{llll}
\hline Strategy Group & Metacognitive (M) & Cognitive (C) & Social (S) \\
\hline Number of Strategies & 17 & 9 & 4 \\
Strategy Usage Total & 2.338 & 1.164 & 567 \\
Average Usage & $138(79 \%)$ & $129.3(74 \%)$ & $142(81 \%)$ \\
\hline
\end{tabular}

Cognitive strategy was accounted for 129.3 (74\%). This strategy consists of the strategy to produce writing which refers to the experience of the writer; and the strategy to create writing which reflects the messages as well as supply monolingual and bilingual dictionary. Another strategy is giving attention to the meaning, including an explanation of what the writer wants to say in writing if the writer has a lack of word while thinking to make the first language in the second language (English). The writer also uses a grammatical structure to make short and simple sentences.

The social strategy was accounted 142 (81\%). There are four strategies, such as cooperating with others by sharing and discussing ideas with the teachers or other students and getting feedback from the students or teachers to improve the writing, which then followed by giving suggestions to the next assignment.

\section{The learners' problems in learning writing}

The researcher had found the learners' problems, which are explained as follows. The first problem is the absence of ideas. It can be seen from the first learner's answered

\section{"Sometimes I find the problem when I feel difficult to explain in a writing about what I think."}

This excerpt tells that the learner did not have ideas about what to write. He knew that he would not be able to write if he did not know what to write.

The second problem is about outlining ideas. It can be seen from the answer to the second learner.

\footnotetext{
"I have difficulty to organize the ideas of writing to become interesting sentences to read."
}

This student expressed his difficulty in how to put the ideas in a logical order. He might forget how an idea should be developed in the form of a paragraph.

The third problem is the difficulties in grammar. It can be seen from the answer of the third learner.

"I have a problem in grammar and sometimes I also forgot the tenses. It makes me find it hard to write." 
Grammar seemed to be the most challenging issue for this student. He pointed out that grammar, which also included knowledge of tenses, had hindered him from being able to write.

The fourth problem is the relation between the idea and the writer's mood. It can be seen from the next learner's answered

\footnotetext{
"My difficulty in learning writing is about mood and idea. They are interrelated. If I am in a good mood, I will have a lot of ideas to write. But if I am in a bad mood, I have lack of ideas. I can't write."
}

This student said that he is moody. He can only write when he has a good mood. However, he will not be able to write if he has a bad mood.

The fifth problem is grammar and diction. It can be seen from the answer of the fifth learner.

\footnotetext{
"Usually, I got confused to determine the correct grammar in writing. Sometimes the grammar that I use is not appropriate. I am also confused for the selection of words to be used in a sentence."

"The difficulty in grammar, sometimes I am confused to arrange it properly. Moreover, I do not have a lot of vocabulary."
}

These students also stated that other than grammar, diction, and vocabulary became an issue for them. Diction is important, especially in academic writing. The wrong choice of words may cause a different interpretation. Similarly, poor vocabulary would hinder them from putting their ideas in the written form.

\section{Discussion}

These students also stated that other than grammar, diction, and vocabulary became an issue for them. Diction is important, especially in academic writing. The wrong choice of words may cause a different interpretation. Similarly, poor vocabulary would hinder them from putting their ideas in the written form.

\section{Interpretation of the questionnaire finding}

The researchers found that three strategies were usually used in writing English process. Each strategy showed in different percentages; metacognitive strategies $79 \%$, cognitive strategies $74 \%$, and social strategies $81 \%$. These strategies are needed to help the learners to produce good writing products. In the writing process, firstly, the students need to think of the theme or topic. They also need to think of the topic sentence and some supporting ideas and conclusions. This process is called planning, which includes metacognitive strategies. Planning is important for writers to do good writing (Al-jarrah, Mansor, Talafhah \& Al-jarrah, 2018). This is an important strategy because the learners need to think of how to construct the ideas into correct sentences that are academically acceptable. After that, they can continue in the next step, which called execution. In this step, all the ideas which might have been written in a draft are written. Then the learners need to re-read their writing in order to check the grammar, spelling, and ideas. However, if they give too much attention to the grammar issue, the writing will be such a hinder (Krapels cited in Knospe, 2017). 
Based on the result, the researchers assumed that these strategies (metacognitive, cognitive, and social) are appropriate for the learners. Each strategy relates to another strategy. It can be seen in the writing process; the learners use these strategies to improve their writing. Mistar, Zuhairi, \& Parlindungan (2014) stated that metacognitive and cognitive strategies have important roles in learning writing. Therefore, giving attention to those strategies will help learners improve their writing.

Anita, as cited in Bai, Hu, \& Gu (2014) argued that cognitive activities might consist of all activities that take place in the brain in order to acquire a foreign language. Relating this definition to the micro- and macro-skills of writing proposed by Brown cited in Nguyen (2016). It can be said that cognitive strategy can promote micro-skills of writing, which deal significantly with words, patterns, and meanings, which work absolutely in the brain of the writers. The cognitive strategy, however, varies among learners as they may employ different language processing strategies (Cohen \& Macaro, 2009). In the present study, execution and revision included in cognitive that the learners have different writing. Thus, lecturers should be aware of and understand the differences in cognitive processes of the learners so that they can provide teaching-learning activities that suit the students' cognitive strategies.

Social strategy includes planning and revising the writing. Planning and revising processes share and give feedback on ideas. The benefit of revising process is giving feedback to the peer. Lecturers have to create peer feedback activities for the development of writing. In fact, learners feel stressed when they do the writing process. To solve this problem, they need another participant to help them in developing their writing. Others (lecturer and friends) suggestions can motivate the learners to write because the lecturer and their friends will give feedback to improve the writing product. Pearson's correlation coefficient was established in the sample. However, it was not statistically significant since it only showed a weak positive correlation between the students' strategy and their marks. The possible explanation for this could be the fact that it may not be enough to know or use a variety of strategies. What is vital, the researcher assumes, is to have the understanding and self-awareness of the effectiveness of the strategies as measured against the goal achievement (Zimmerman, 2016).

\section{Interpretation of the findings of the interview}

The problems in learning writing can be seen in some parts, such as grammar, vocabulary, diction, ideas, and writing mood. However, the major language issues of six people interviewed are grammar and vocabulary. Fareed, Ashraf, \& Bilal (2016) had found a similar problem in their study. They identified that grammar and vocabulary became the main issues for students in learning writing. Haider (2012) also found a problem with vocabulary in his study. For the learners, grammar and vocabulary knowledge are considered significant to be able to write well. This should inspire the teachers to allocate more time to pay more attention to grammar and vocabulary. It is true that without sufficient vocabulary, learners would not be able to express their ideas. Similarly, without a good knowledge of grammar, their writing will potentially be misinterpreted. Therefore, the teaching of grammar and vocabulary needs to receive more attention from the teacher.

\section{Conclusion}

This study examined the categories of strategies in learning writing used by learners of English Education Department, and the strategies results based on the stages of the writing 
process, namely planning, writing, and revising. It is alongside the three-factor models: cognitive, metacognitive, and social strategies that are accounted for average used in each strategy for $79 \%$ of metacognitive strategy, $74 \%$ for cognitive strategy, and $81 \%$ for social strategy. Meanwhile, the finding on the learners' problems in writing showed that the major language issues are grammar and vocabulary. It shows that time allocation for grammar and vocabulary needs to be increased. Therefore, the researchers would like to offer some suggestions the future research. It would be interesting and beneficial if the further study looks into the teacher's strategy in teaching writing. It will give a more comprehensive picture of how to improve the students' writing skills from the students' side and the teacher's side.

\section{Acknowledgment}

The researchers would like to express their greatest gratitude and honor to the students who have been involved in this study and the lecturers who have allowed their classes to be used for data collection.

\section{References}

Al-jarrah, T. M., Mansor, N., Talafhah, R. H., \& Al-jarrah, J. M. (2018). The Application Of Metacognition, Cognitivism, And Constructivism In Teaching Writing Skills. European Journal of Foreign Language Teaching, 3(4), 199-213.

https://doi.org/10.5281/zenodo.2531617.

Aygün, S., \& Aydın, S. (2016). The use of e-portfolios in EFL writing: A review of literature. ELT Research Journal, 5(3), 205-217

Bai, R., Hu, G., \& Gu, P. Y. (2014). The relationship between use of writing strategies and English proficiency in Singapore primary schools. The Asia-Pacific Education Researcher, 23(3), 355-365.

Cohen, A. D., \& Macaro, E. (2009). Language learner strategies: 30 years of research and practice. Language, 13(2).

Davidson, C. (2007). Independent Writing in Current Approaches to Writing Instruction: What We Overlooked?. English Teaching Practice and Critique, 6(11), 11-24.

Ellis, A. K., Denton, D. W., \& Bond, J. B. (2014). An analysis of research on metacognitive teaching strategies. Procedia - Social and Behavioral Sciences, 116, 4015-4024. https://doi.org/10.1016/j.sbspro.2014.01.883

Fareed, M., Ashraf, A., \& Bilal, M. (2016). ESL learners' writing skills: Problems, factors and suggestions. Journal of Education and Social Sciences, 4(2), 81-92.

Habók, A., \& Magyar, A. (2018). Validation of a self-regulated foreign language learning strategy questionnaire through multidimensional modelling. Frontiers in psychology, 8 , 1-8

Haider, G. (2012). An insight into difficulties faced by Pakistani student writers: Implications for teaching of writing. Journal of Educational and Social Research, 2(3), 17-27.

Harmer, J. (2004). How to Teach writing. England: Pearson Education Limited.

Hayes, J. R., \& Flower, L. (2015). Identifying the organization of writing processes. Carnegie Mellon University.

Jin, L., Jiang, C., Zhang, J., Yuan, Y., Liang, X., \& Xie, Q. (2014). Motivations and expectations of English language learning among primary school children and parents in China. ELT Research papers, 1-33.

Kalati, E. A. (2016). Learning strategies in second language acquisition. Research \& Reviews: Journal of Educational Studies, 2(4), 4-8. 
Knospe, Y. (2017). Writing in a third language: a study of upper secondary students' texts, writing processes and metacognition (Doctoral dissertation, Umeå University).

Maarof, N., \& Murat, M. (2013). Writing strategies used by ESL upper secondary school students. International Education Studies, 6(4), 47-55.

Mistar, J., Zuhairi, A., \& Parlindungan, F. (2014). Strategies of Learning English Writing Skill by Indonesian Senior High School Students. Arab World English Journal, 5(1).

Montaño-González, J. X. (2017). Learning Strategies in Second Language Acquisition. USChina Foreign Language, 15(8), 479-492.

Nguyen, H. T. T. (2016). Macro and micro skills in second language academic writing: $A$ study of Vietnamese learners of English (Doctoral dissertation, Southern Illinois University Carbondale).

Oxford, R. L. (2017). Teaching and Researching Language Learning Strategies: SelfRegulation in Context. New York: Routledge.

O'Malley, J. M., Chamot, A. U., Walker, C., \& Sabol, M. A. (1987). The role of learning strategies in second language acquisition: A model for research in listening comprehension. US Army: Interamerica Research Associates.

Ruhama, U., Purwaningsih, D.I. (2018). Improving student's writing skills through the application of synectic model of teaching using audiovisual media. English Language Teaching Educational Journal, 1(3), 176-190.

Salikin, H., Bin-Tahir, S. Z., \& Emelia, C. (2017). The Higher Achiever Students' Strategies in English Learning. Modern Journal of Language Teaching Methods, 7(11), 79-95.

Shi, H. (2017). Learning strategies and classification in education. Institute for Learning Styles Journal, 1(Fall), 25-36.

Stephanou, G., \& Mpiontini, M. H. (2017). Metacognitive Knowledge and Metacognitive Regulation in Self-Regulatory Learning Style, and in Its Effects on Performance Expectation and Subsequent Performance across Diverse School Subjects. Psychology, 8(12), 1941.

Tawalbeh, A., \& Al-zuoud, K. M. (2013). The Effects of Students' Prior Knowledge of English on Their Writing of Researches. International Journal of Linguistics, 5(3), 156-163.

Tillema, M., Van Den Bergh, H., Rijlaarsdam, G., \& Sanders, T. (2011). Relating self reports of writing behaviour and online task execution using a temporal model. Metacognition and Learning, 6(3), 229-253.

Torrance, M., Thomas, G. V., \& Robinson, E. J. (1994). The writing strategies of graduate research students in the social sciences. Higher education, 27(3), 379-392.

Yusuf, Q., Jusoh, Z., \& Yusuf, Y. Q. (2019). Cooperative Learning Strategies to Enhance Writing Skills among Second Language Learners. International Journal of Instruction, 12(1), 1399-1412.

Zimmerman, B. J. (2016). Self-Regulated Learning and Academic Achievement: An Overview Self-Regulated Learning and Academic Achievement: An Overview. Educational Psychologist, 25 (1), 3-17. 